\title{
Hepatitis B and the infected health care worker: Public safety at what cost?
}

\author{
Mamatha Bhat MD¹, Peter Ghali MD¹, Marc Deschenes MD¹, Philip Wong MD ${ }^{1}$
}

\begin{abstract}
M Bhat, P Ghali, M Deschenes, P Wong. Hepatitis B and the infected health care worker: Public safety at what cost? Can J Gastroenterol 2012;26(5):257-260.

Public safety and the right of the health care worker to practise without prejudice based on underlying illness may be at odds for those affected by the hepatitis B virus (HBV). Nevertheless, HBV does not preclude entry into a health care profession, and the risk of transmission from health care worker to patient is not uniform across the spectrum of health care fields. In the present article, the authors present an overview of the literature regarding transmission of HBV from the health care worker to the patient, and the current recommendations that vary from province to province within Canada. The establishment of national guidelines to standardize monitoring of HBV infection among health care workers would improve health care workplace safety and patient care.
\end{abstract}

\author{
L'hépatite B et le travailleur de la santé infecté : \\ la sécurité publique à quel prix?
}

La sécurité publique peut être en porte-à-faux avec le droit des travailleurs de la santé d'exercer sans préjudice fondé sur une maladie sousjacente lorsque ceux-ci sont atteints du virus de l'hépatite B (VHB). Néanmoins, le VHB n'empêche pas l'admission dans une profession de la santé, et le risque de transmission entre un travailleur de la santé et un patient n'est pas uniforme dans l'ensemble du spectre des professions de la santé. Dans le présent article, les auteurs donnent un aperçu des publications sur la transmission du VHB entre un travailleur de la santé et un patient, et exposent les recommandations actuelles qui varient d'une province à l'autre au Canada. La création de directives nationales pour normaliser la surveillance de l'infection par le VHB chez les travailleurs de la santé améliorerait la sécurité en milieu de travail et les soins aux patients.

Key Words: Hepatitis B; Health care worker; Prevention; Transmission

40-year-old surgeon recently recruited to your hospital is found to A have elevated liver enzyme levels. His serum biochemistry reveals alanine aminotransferase $70 \mathrm{IU} / \mathrm{mL}$ (normal $6 \mathrm{IU} / \mathrm{mL}$ to $31 \mathrm{IU} / \mathrm{mL}$ ), aspratate aminotransferase $46 \mathrm{IU} / \mathrm{mL}$ (normal $6 \mathrm{IU} / \mathrm{mL}$ to $35 \mathrm{IU} / \mathrm{mL}$ ), alkaline phosphatase $88 \mathrm{IU} / \mathrm{mL}$ (normal $25 \mathrm{IU} / \mathrm{mL}$ to $115 \mathrm{IU} / \mathrm{mL}$ ) and normal hepatic function tests. He is hepatitis B surface antigen ( $\mathrm{HBsAg}$ ) positive, hepatitis $\mathrm{B}$ core antibody positive, hepatitis $\mathrm{B}$ e antigen ( $\mathrm{HBe} A \mathrm{~g})$ negative, hepatitis $\mathrm{B}$ e antibody positive and has hepatitis $\mathrm{B}$ virus (HBV) DNA level of $4.8 \times 10^{5} \mathrm{IU} / \mathrm{mL}$.

This case illustrates a common scenario in hospital infection control: should a doctor with active HBV infection be allowed to perform invasive procedures despite the potential risk of transmission with blood contact, or is it a breach of the doctor-patient contract when patients have not been informed of the doctor's HBV status?

This scenario can be evaluated with a contextual appreciation of HBV epidemiology, rates of transmission and the currently available guidelines. In the present article, we review the various facets of HBV infection, and link them to the ethical dilemma of the HBV-infected health care worker (HCW).

There are an estimated 370 million chronic carriers of HBV worldwide, with more than $75 \%$ of these people living in the Western Pacific and Asia (1). In Canada, between $0.7 \%$ and $0.9 \%$ of the population is estimated to be chronically infected, and $5 \%$ have a remote history of acute infection, figures that are likely to rise with the increasing mobility of individuals from one country to another (2). According to the $\mathrm{WHO}, \mathrm{HBV}$ is the ninth leading cause of death worldwide, with approximately two million people dying annually from hepatocellular carcinoma and complications of cirrhosis secondary to HBV by the fifth or sixth decades of life in those with chronic infection. HBV can survive in dried blood for up to seven days at $25^{\circ} \mathrm{C}$, and is significantly more infectious than either hepatitis $\mathrm{C}$ or HIV, with a reported transmission rate of up to $30 \%$ from needlestick injuries (3). This rate seems to correlate with serum HBV DNA concentrations. In Western countries, transmission occurs predominantly via sexual and parenteral contact between adults. In the endemic countries of Asia, HBV is transmitted mainly during the perinatal period (vertical transmission) or in childhood (horizontal), resulting in a higher risk of chronicity. The concentration of HBV varies across body fluids, with blood, serum and wound exudates carrying the highest concentrations; semen, vaginal fluid and saliva carrying moderate concentrations; and urine, feces, sweat and breast milk containing the lowest concentrations, which translates into the lowest risk of HBV transmission (4).

\section{HOW CAN HBV BE TRANSMITTED BY HCWs TO PATIENTS?}

Given that HBV is a condition that is preventable by vaccination, all individuals should ideally be vaccinated as a precaution before entering the health care workforce (5). The HBV vaccine offers a $95 \%$ to $99 \%$ protective immune response that has proven long-term efficacy (up to $80 \%$ protection at 16 years after vaccination) (6). Although HBV infection rates among HCWs were higher than that of the general population before development of the HBV vaccine, this situation has been reversed, with many $\mathrm{HCW}$ s having previously received the vaccine $(7)$.

HBV is the blood-borne communicable disease (BBCD) most likely to be contracted through needlestick injury, and has been reported to be transmitted at a rate of 24 to 2400 per $1,000,000$ procedures $(0.002 \%$ to $0.24 \%$ ) (8). At least 52 transmissions of HBV from infected HCWs to more than 500 patients have been documented. Reported infection rates have decreased in areas where HBV vaccination has been widely implemented (9). Factors associated with HBV transmission are: HBV DNA level; HBeAg status; type of surgery; duration of surgery; volume of blood transmitted; the route of transmission (percutaneous versus mucosal); and procedural skill level (10). In fact, $\mathrm{HBe} \mathrm{Ag}$-positive status is associated with a transmission rate of $19 \%$ to $30 \%$, and $\mathrm{HBeAg}$-negative status with a transmission rate of $5 \%$; however, these figures do not account for variations in HBV DNA levels (11).

In the health care setting, transmission may occur via several routes, but the most frequent route leading to establishment of HBV infection is through needlestick injury. Invasive surgical procedures

Department of Gastroenterology $\mathcal{E}$ Hepatology, McGill University Health Centre

Correspondence: Dr Mamatha Bhat, Division of Gastroenterology, McGill University Health Centre, 687 Pine Avenue West, Montreal,

Quebec H3A 1A1. Telephone 514-843-1616, fax 514-843-1421, e-mail mamatha.bhat@mail.mcgill.ca

Received for publication July 14, 2011. Accepted August 16, 2011 
are another route of HBV transmission; in fact, surgeons represent the largest group of HCWs involved in provider-to-patient HBV transmission (8). A physician who has contracted a BBCD is deemed to be an 'affected physician' when his/her clinical status is such that it poses a risk of BBCD transmission to a patient with inadvertent exposure to the physician's blood (12). Other HCWs implicated in cases of HBV transmission have included a respiratory therapist, cardiac pump technicians and an electroencephalography technician (9). However, it is the regular performance of an exposure-prone procedure (EPP) that is mainly of concern. EPPs are defined as procedures in which there is a risk that injury to the physician may result in the exposure of the patient's open tissues to the blood of the physician (otherwise known as 'bleedback'). Any type of invasive surgery is, thus, an EPP, wherein the affected physician's gloved hand is in constant contact with sharp instruments, needle tips or sharp tissues (spicules of bone or teeth) inside a patient's open body cavity. Surgery performed within a confined anatomical space, where the hands or finger tips may not always be completely visible, also carries an elevated risk of transmission given the paucity of surgical precision and control in this context. A procedure is considered to be non-exposure-prone (NEPP) when the hands and fingertips of the physician are visible and outside the patient's body throughout, even when there is handling of sharp instruments. A NEPP can become an EPP if a patient is uncooperative.

Retrospective studies have evaluated the rate of HBV transmission from affected physicians through blood contact during specific types of EPPs. Percutaneous injuries have been reported to occur in $6.9 \%$ of operations and, in $32 \%$ of these instances, the instigating sharp instrument touches the patient wound once again (13). The risk of HBV transmission is not negligible; the rate in cardiothoracic surgery is reported to be $6 \%$ to $13 \%(14,15)$, up to $9 \%$ in gynecological surgery $(16,17)$ and $2 \%$ in general surgery $(18,19)$. The proportion of patients infected with HBV secondary to transmission from an infected HCW (IHCW) is between $0.5 \%$ and $13.1 \%(20)$.

A 2006 Cochrane review (21) recommended that HCWs who were HBV or HCV infected double-glove during all procedures to decrease the risk of transmission. Other strategies that might help in decreasing the rate of transmission include: a training program for $\mathrm{HCW}$ about risk factors and preventive measures; adoption of safety medical sharp devices (eg, blunt-tip suture needle versus sharp needle); and modification to the organizational environment (eg, limiting work hours to decrease the risk for errors).

Postexposure prophylaxis depends on the vaccination status and vaccine-response status of the exposed person. As per Centers for Disease Control (Georgia, USA) guidelines, unvaccinated persons should receive a single dose of $\mathrm{HBV}$ immunoglobulin, preferably within $24 \mathrm{~h}$ of exposure, followed by the HBV vaccine series. This approach to prophylaxis is $90 \%$ effective in preventing establishment of HBV infection (22).

\section{WHAT ARE THE CURRENT GUIDELINES ON HBV IN IHCWs?}

The dilemma presented by the case at the outset of the present article merits the establishment of a concrete approach to such situations. Ideally, HCWs should be vaccinated before entering professional training programs. However, there are health care centres in which HBV status is not routinely checked, and there is a sizeable number of health care professionals entering the workforce who acquired $\mathrm{HBV}$ in childhood.

There have been no documented studies of HBV prevalence among HCWs in Canada. No universally agreed on consensus guidelines currently exist; guidelines vary from country to country and, in Canada, from province to province. Present-day policies with respect to IHCWs, and the limits to be placed on their clinical practice, vary from country to country.

Some guidelines estimate the level of infectivity of the IHCW based on HBeAg status only, whereas others use HBV DNA levels. Most 'effective' transmissions have occurred when the IHCW carries
HBV DNA $>1.9 \times 10^{5} \mathrm{IU} / \mathrm{mL}\left(10^{6}\right.$ copies $/ \mathrm{mL}$, with conversion factor of 5.26 copies per IU). Establishing a threshold for the limitation of EPPs would have to account for a $3 \log _{10}$ safety margin to account for assay variability (13).

Health Canada's Laboratory Centre for Disease Control (LCDC) issued a consensus statement on the risk of transmission of bloodborne pathogens by IHCWs in 1998 (5). The central recommendation was that HBV testing and immunization be made mandatory for all HCWs. HBeAg-positive IHCWs would be obliged to stop practicing EPPs pending decision by an expert committee. HBeAg-negative individuals could continue performing EPPs, but they too had to be referred to a committee of HBV experts for a more in-depth assessment of eligibility to continue performing invasive procedures. In 1998, the Canadian Medical Association issued a policy that favoured a more voluntary route of screening and vaccination for $\mathrm{HBV}$, and recommended referral to an expert committee if a HCW tested positive for HBsAg (23).

Most Canadian provinces have developed more nuanced guidelines since then. The College of Physicians and Surgeons of Saskatchewan stipulates that $\mathrm{HBeAg-positive} \mathrm{IHCWs} \mathrm{should} \mathrm{not}$ perform EPPs or NEPPs (24). The guidelines of the Colleges of Saskatchewan and British Columbia both specify that $\mathrm{HBeAg}$ negative IHCWs with HBV DNA levels $>1000 \mathrm{IU} / \mathrm{mL}$ should not be allowed to perform EPPs, whereas those with levels $<1000 \mathrm{IU} / \mathrm{mL}$ could be permitted to do so (25). The practice of both EPPs and NEPPs by $\mathrm{HBeAg}$-negative IHCWs with HBV DNA $>100,000 \mathrm{IU} / \mathrm{mL}$ was forbidden. Those with levels between $1000 \mathrm{IU} / \mathrm{mL}$ and 100,000 IU/mL are allowed to practice NEPPs only. The recently issued Quebec guidelines (26) have gone one step further by recommending that IHCWs practise EPPs only if five consecutive measurements of HBV DNA $<200 \mathrm{IU} / \mathrm{mL}$ at three-month intervals be documented before allowing an IHCW to perform an EPP. The Colleges of Physicians and Surgeons of Ontario, Manitoba, Alberta and Yukon have decided to adopt a case-by-case approach to management of IHCWs with BBCDs through expert review panels for bloodborne infections in HCWs (27-30). They emphasize that it is the ethical responsibility of a physician practicing EPPs who learns that he/she is positive for a BBCD to contact the College for a review of his/her practice. The colleges of other provinces and territories were contacted and their websites searched; however, none had an official guideline document.

An expert panel was convened by the Canadian Medical Protection Association to issue recommendations concerning physicians with blood-borne infections (31). It supported mandatory testing for bloodborne infections among physicians practicing EPPs, given the important number of transmissions to patients that have occurred in this context. The panel cited that current evidence did not support conducting such testing for those not performing EPPs. It also recommended that physicians with HBV DNA > $2000 \mathrm{IU} / \mathrm{mL}$ not perform EPPs unless the patient had natural immunity or an active HBV infection.

The 2010 Society for Healthcare Epidemiology of America (SHEA) guidelines (32) are similar, in that they allow for EPPs to be performed as long as the HBV DNA level is $<2000 \mathrm{IU} / \mathrm{mL}$ (ie, $10^{4}$ copies $/ \mathrm{mL}$ ).

Establishment of HBV DNA thresholds is hindered by a few major caveats: the fluctuation in HBV DNA levels over time; the reliability and reproducibility of the assay used to measure HBV DNA; and the safety margin allowed. Such a situation occurred in the case of an HBeAg-negative orthopedic surgeon in Britain with an HBV DNA level $<2000 \mathrm{IU} / \mathrm{mL}\left(10^{4}\right.$ copies $\left./ \mathrm{mL}\right)$ who infected a patient during a hip repair with fatal consequences (33). There can be a great deal of variability in HBV DNA levels among HBeAg-negative individuals, especially those with precore mutants. A study of the antiviral agent adefovir by Marcellin et al (34) revealed that $47 \%$ of patients on placebo had $1 \log _{10}$ to $5 \log _{10}$ fluctuations in HBV DNA levels $\left(10^{4}\right.$ copies $/ \mathrm{mL}$ to $10^{9}$ copies $/ \mathrm{mL}$ ). An estimated one-fifth of $\mathrm{HBeAg}$-negative individuals carry these mutants, and, thus, should not be performing EPPs (35). 


\section{WHAT ARE THE ETHICAL AND MEDICOLEGAL IMPLICATIONS OF HBV IN IHCWs?}

All physicians have an ethical responsibility to know their serological status with respect to BBCDs if they practice EPPs.

The decision as to whether an IHCW with HBV can continue to practice has a number of ethical and medicolegal ramifications. There are three parties whose interests need to be considered in this debate: the HCW; the patient; and society. The HCW has a right to privacy and freedom from discrimination based on his HBV status, and should be allowed to further his/her career and contribute to the health care system given the numerous invested years of training. Inappropriately restricting a physician's practice could mean denying patients proper access to health care. Also, the patient has a right to informed choice, autonomy and protection from harm. In the context of universal health care, society aims to maintain an affordable and efficient health care system, at the same time avoiding the burdens incurred from permitting practice by an IHCW (36).

Patient advocates have proposed full disclosure by IHCWs to patients before performing EPPs. However, the patient may not have the necessary insight to appreciate the actual minimal risk of transmission, leading to an exaggerated perception of this risk and request of referral to an alternative $\mathrm{HCW}$. On the other hand, if a patient were already immunized, transmission would not be an issue. Disclosure is also an infringement of a HCW's right to privacy (37). Nevertheless, there is a serious medicolegal implication when a patient is infected by a HCW and HBV status was not previously disclosed. The level of risk society is willing to accept should be factored into consensus guidelines given these medicolegal ramifications. In fact, Canadian courts have deemed a risk of transmission $<1 \%$ as important enough to be disclosed if the consequences are considered to be serious (38). A survey of a Scottish HBeAg-positive dentist's patient population was conducted following a letter informing them of his HBV status (39). Ninety-three per cent of the sampled population believed that patients should always be informed of the possibility of infectious contact, even if the risk was quite low.

If a modification to practice is made such that EPPs are avoided, disclosure should not be necessary (38). The IHCW should be counselled to pursue nonexposure-prone specialties. Routine physical examinations, and oral, vaginal and rectal examinations may be performed. Other acceptable procedures are venipucture, inserting

\section{REFERENCES}

1. World Health Organization, Hepatitis B factsheet number 204, $<$ www.who.int/mediacentre/factsheets/fs204/en/> (Accessed January 5, 2011).

2. Public Health Agency of Canada. Hepatitis B: Get the facts. <www.phac-aspc.gc.ca. 2010> (Accessed January 5, 2011).

3. Division of Viral hepatitis B, Centers for Disease Control and Prevention. Hepatitis B Frequently asked questions <www.cdc. govNCIDOD/DISEASE/HEPATITIS/b/faqb.htm> (Accessed December 6, 2006).

4. Canadian Centre for Occupational Health and Safety. Hepatitis B factsheet. <www.ccohs.ca/oshanswers/diseases/hepatitisb.html> (Accessed January 5, 2011).

5. Health Canada's Laboratory Centre for Disease Control (LCDC): Proceedings of the Consensus conference on infected healthcare workers: Risk for transmission of bloodborne pathogens. Can Commun Dis Rep 1998;24(Suppl 4).

6. Shamsizadeh A, Makvandi M, Shoshtari G. Prevalence of anti hepatitis B surface antibody among children in Ahvaz, Iran, five years after vaccination. JJM 2011;4:49-54.

7. Mahoney F, Stewart K, Hu H, Coleman P, Alter M. Progress toward the elimination of hepatitis B virus transmission among health care workers in the United States. Arch Intern Med 1997;157:2601.

8. Bell D, Shapiro C, Culver D, Martone W, Curran J, Hughes J. Risk of hepatitis B and human immunodeficiency virus transmission to a patient from an infected surgeon due to percutaneous injury during an invasive procedure: Estimates based on a model. Infect Agents Dis 1992;1:263-9. intravenous lines or central lines (provided that there has been no skin tunneling and the procedure is performed in a nonexposure-prone manner), minor surface suturing, incision and drainage of external abscesses and simple endoscopic procedures.

The decision to commence treatment for HBV in IHCWs should be made judiciously. Treating IHCWs inappropriately, for example, if they are in the immune tolerance phase and have very high HBV DNA level, is inadvisable and would result in the development of drug resistance.

Our review summarizes the current knowledge regarding transmission of HBV by HCWs in the health care setting, along with the existing Canadian provincial guidelines on this issue. It would be important to conduct a nationwide survey to estimate the prevalence of HBV infection among physicians and nurses, as well as any other health care professionals involved in the performance of EPPs or NEPPs. Subsequent to this survey, it would be informative to determine the economic impact of following these guidelines and its effect on the workforce.

There are a large number of chronic HBV carriers worldwide, and the Canadian workforce is dependent on the increasing mobility of individuals from one country to another, including HBV-endemic countries. As it stands, Canada has a significant health care labour shortage, with approximately five million Canadians (15\% of the population) having no access to a family physician (40). Verifying HCWs for evidence of HBV infection should be routine before entry into the workforce. If HBV infection is detected, there is currently no universal standard approach to guide management. The establishment of national consensus guidelines addressing the issue of $\mathrm{HBV}$ infection among HCWs would enable greater portability of HCWs, and avoid the inconsistencies among the provincial statements. This would ensure a safer working environment for doctors and patients, and translate into overall better health care outcomes.

\section{The case revisited}

The surgeon is in the active chronic HBeAg-negative phase of HBV infection. Therefore, he needs to advise his provincial College of Physicians and the hospital authorities of his infectious status. He would not be permitted to perform EPPs, but eligibility to perform NEPPs varies by provincial jurisdiction. He should be referred to a physician with expertise in the management of viral hepatitis.

9. Carlson A, Perl T. Health care workers as source of hepatitis B and C virus transmission. Clin Liv Dis 2010;14:153-68.

10. Bell D, Shapiro C, Ciesielski C, Chamberland M. Preventing bloodborne pathogen transmission from health-care workers to patients. The CDC perspective. Surg Clin North Am 1995;75:1189-203.

11. Transmission of hepatitis $B$ to patients from four infected surgeons without hepatitis B e antigen. The Incident Investigation Teams and others. N Engl J Med 1997;336:1780-84.

12. Health Canada. Proceedings of the Consensus conference on infected healthcare workers: Risk for transmission of bloodborne pathogens. Can Commun Dis Rep 1998;24(Suppl 4):1-28.

13. Schalm S, Buster E. Management of hepatitis B virus infected health care workers based on HBV DNA levels. J Clin Virol 2003;27:231-4.

14. Prentice M, Flower A, Morgan G, et al. Infection with hepatitis B virus after open heart surgery. BMJ 1992;304:761.

15. Harpaz R, Von Seidlein L, Averhoff F, et al. Transmission of hepatitis $B$ virus to multiple patients from a surgeon without evidence of inadequate infection control. N Engl J Med 1996;334:549-54.

16. Lettau L, Smith J, Williams D, et al. Transmission of hepatitis B with resultant restriction of surgical practice. JAMA 1986;255:934.

17. Welch J, Tilzey A, Webster M, Noah N, Banatvala J. Hepatitis B infections after gynaecological surgery. Lancet 1989;333:205-7.

18. Corden S, Ballard A, Ijaz S, et al. HBV DNA levels and transmission of hepatitis B by health care workers. J Clin Virol 2003;27:52-8. 
19. Spijkerman I, van Doorn L, Janssen M, et al. Transmission of hepatitis $B$ virus from a surgeon to his patients during high-risk and low-risk surgical procedures during 4 years. Infect Control Hosp Epidemiol 2002;23:306-12.

20. Hasselhorn H, Hofmann F. Transmission of HBV, HCV and HIV by infectious medical personnel - presentation of an overview. Der Chirurg; Zeitschrift für alle Gebiete der operativen Medizen 2000;71:389.

21. Tanner J, Parkinson H. Double gloving to reduce surgical crossinfection (Cochrane Review). The Cochrane Library 2003;2:1-32.

22. Public Health Service guidelines for the management of occupational exposures to HBV, HCV, and HIV and recommendations for postexposure prophylaxis. MMWR Recomm Rep 2001;50:1-42.

23. Sibbald B. CMA says no to mandatory hepatitis $B$ vaccination, screening for MDs. CMAJ 1998;159:64.

24. College of Physicians and Surgeons of Saskatchewan. Guidelines of the Expert Advisory Committee on Bloodborne Communicable Diseases. November 2008.

25. College of Physicians and Surgeons of British Columbia. Resource Manual - Bloodborne Communicable Diseases in Physicians. $<$ www.cpsbc.ca> (Accessed January 5, 2011).

26. Beliveau C, Cote R, Miller M, Robillard P, Wong P. Recommandations Comite Scientifique Sertih - Virus Hepatite B. Octobre $2010<$ www.inspq.qc.ca> (Accessed on Janusry 10, 2011).

27. College of Physicians and Surgeons of Ontario Policy Statement. Physicians with Bloodborne Pathogens. Reviewed and Updated in September 2005. <www.cpso.on.ca/policies> (Accessed January 6, 2011).

28. College of Physicians and Surgeons of Alberta. Monitoring Physicians with Bloodborne Infections. Revised Update April 15, 2010. <www.cpso.on.ca/uploadedFiles/policies/policies/policyitems/ bloodborne2005.pdf> (Accessed January 6, 2011).

29. College of Physicians and Surgeons of Manitoba. Physicians with Bloodborne Pathogens Statement 1580. Revised in 2002. <www.cpsm.mb.ca/statements/st1580.pdf> (Accessed January 6, 2011).
30. Yukon Medical Council. Physicians with Bloodborne Pathogens, Policy and Guideline. Approved April 13, 2010 <www.yukonmedicalcouncil.ca/pdfs/blood_borne_Statement.pdf> (Accessed January 5, 2011).

31. Shafran SD, Angel JB, Coffin CS, Grant DR, Jaeschke R, Wong DK. The physician with blood-borne viral infection: What are the risks to patients and what is an appropriate approach to the physicians? < www.cmpa-acpm.ca/cmpapd04/docs/submissions_papers/com preamble_physicians_with_blood_borne_infections-e.cfm> (Accessed January 6, 2011).

32. Henderson D, Dembry L, Fishman N, et al. SHEA guideline for management of healthcare workers who are infected with hepatitis $B$ virus, hepatitis $C$ virus, and/or human immunodeficiency virus. Infect Cont Hosp Epidemiol 2010;31:203-32.

33. Sundkvist T, Hamilton G, Rimmer D, Evans B, Teo C. Fatal outcome of transmission of hepatitis B from an e antigen negative surgeon. Commun Dis Public Health 1998;1:48-50.

34. Marcellin P, Chang T, Lim S, et al. Adefovir dipivoxil for the treatment of hepatitis $\mathrm{B}$ e antigen-positive chronic hepatitis $\mathrm{B}$. N Engl J Med 2003;348:808-16.

35. Boxall E, Ballard A. Fifth of e antigen negative carriers of hepatitis B virus should not perform exposure prone procedures. BMJ 1997;314:144.

36. Luu N. Dental students with Hepatitis B: Issues to be considered when defining policies. J Dental Educ 2004;68:306.

37. Henderson D. The AIDS/Tuberculosis Subcommittee of the Society for Healthcare Epidemiology of America. Management of healthcare workers infected with hepatitis B virus, hepatitis $C$ virus, human immunodeficiency virus, or other bloodborne pathogens. AIDS/TB Committee of the Society for Healthcare Epidemiology of America. Infect Control Hosp Epidemiol 1997;18:349-63.

38. Tereskerz P, Pearson R, Jagger J. Infected physicians and invasive procedures: National policy and legal reality. Milbank Q 1999;77:511-29.

39. Blatchford O, O'Brien SJ, Blatchford M, Taylor A. Infectious health care workers: Should patients be told? J Med Ethics 2000;26:27.

40. Gulli C, Lunau K. Adding fuel to the doctor crisis. Macleans, 2008;17:23-34. 


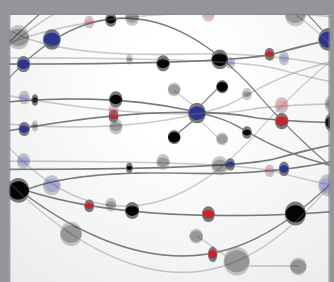

The Scientific World Journal
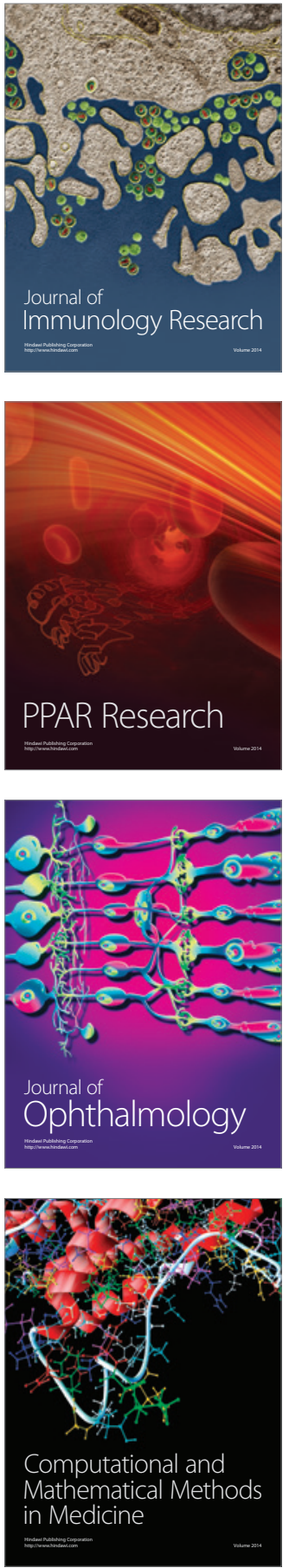

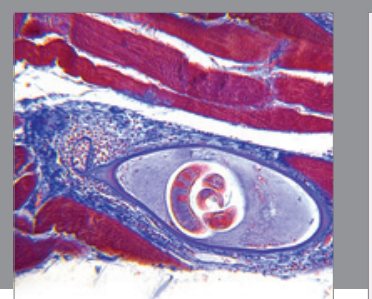

Gastroenterology Research and Practice

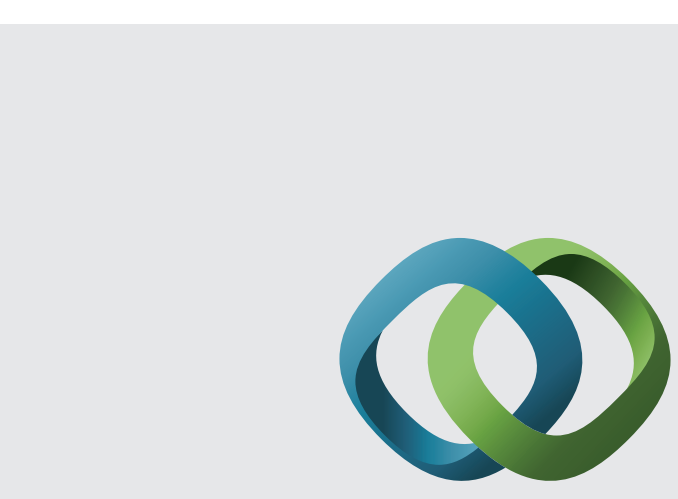

\section{Hindawi}

Submit your manuscripts at

http://www.hindawi.com
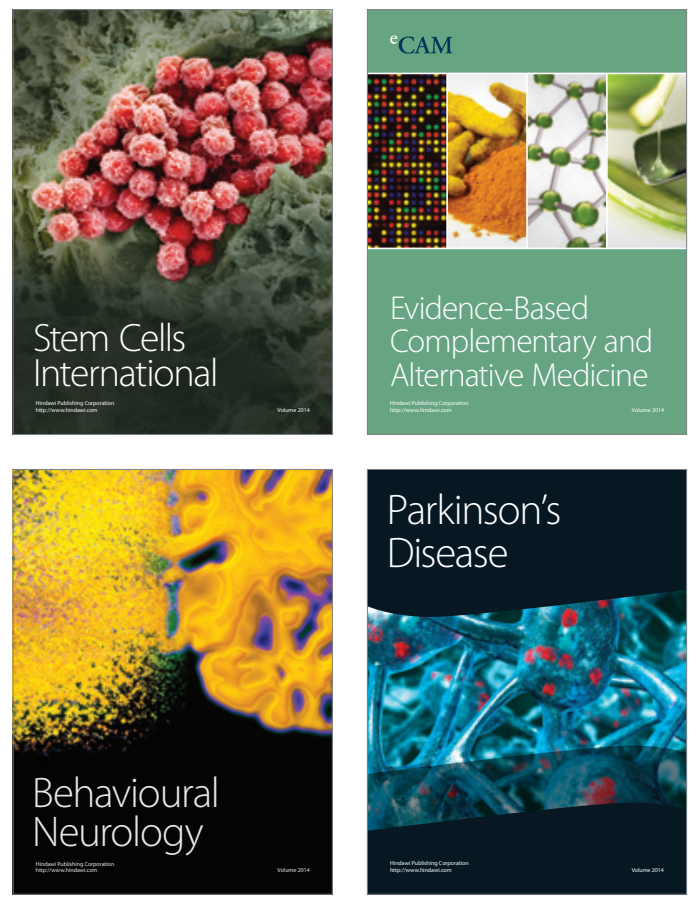
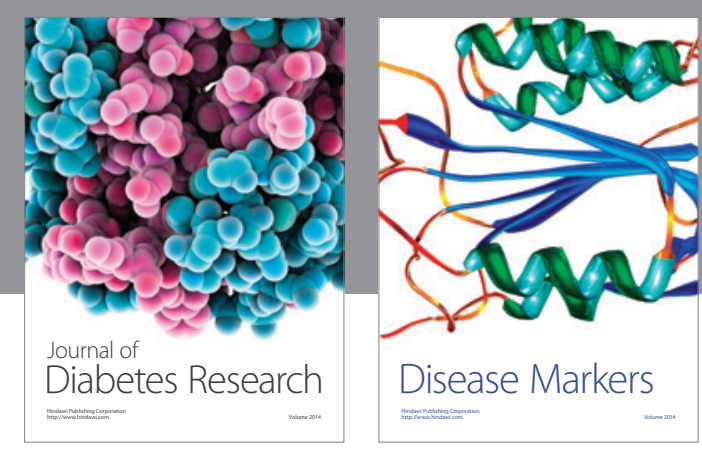

Disease Markers
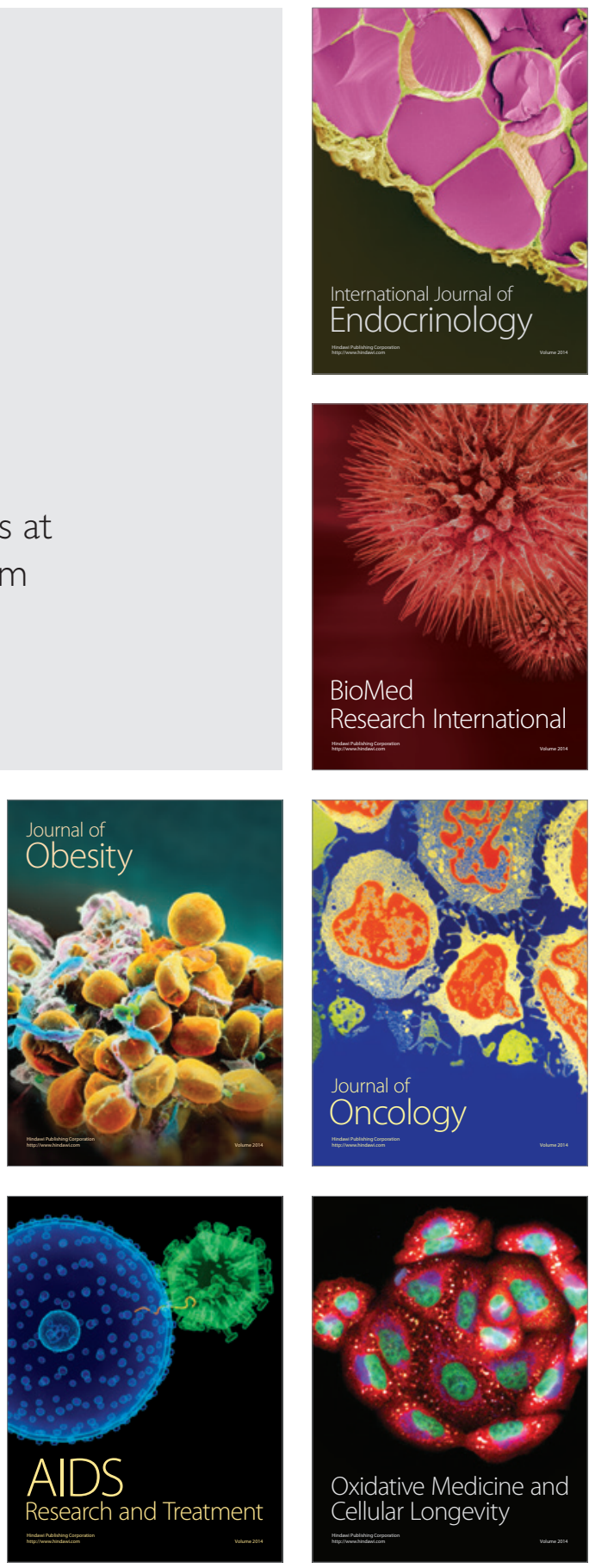